\title{
Development of In-vitro Assays to Estimate Rabies Viral Protein in Vaccine Preparation
}

Thangaraj Sekar ${ }^{\star}$, Ganesan Chandra Mohan, Citrambalam Palaniappan, Ananda Arone Premkumar, Bheeman Sundaran and Balaraman Sekar Pasteur Institute of India, Coonoor, The Nilgiris, Tamilnadu, India

*Corresponding author: Thangaraj Sekar, Assistant Research Officer, Pasteur Institute of India, Research and Development, Coonoor, Tamilnadu 643103, India, Tel: + 9487365795; E-mail: sekar_102000@yahoo.com

Received date: May 29, 2018; Accepted date: June 22, 2018; Published date: June 27, 2018

Copyright: $@ 2018$ Sekar T, et al. This is an open-access article distributed under the terms of the Creative Commons Attribution License, which permits unrestricted use, distribution, and reproduction in any medium, provided the original author and source are credited.

\begin{abstract}
Vaccine against rabies is prepared by cell culture technology and these vaccines are free from many side effects when compared to nerve tissue vaccines. The vaccine production is a continuous process involving propagation of virus, harvesting, concentration, inactivation, purification and formulation with preservatives. The quantification of viral protein in the intermediate biological product is an in-process quality control test to reduce the product loss during various process of vaccine manufacturing. The conventional in-vivo \& in-vitro tests employed for the quantification of rabies viral protein are time consuming, laborious and requires laboratory animals. In this study, we attempted to develop in-house serological methods such as sandwich ELISA, Dot Blot for the detection and quantification of rabies antigen in the intermediate biological material during vaccine preparation. The hyper immune sera was prepared by immunizing two animal models i.e. Guinea Pigs and rabbits with standard Rabies antigen. The sera samples were purified by saturated ammonium sulphate precipitation and further by G50 gel column. The antirabies antibody titre in the purified preparation was estimated using Rapid Fluorescent Focus Inhibition Test (RFFIT). National Reference Rabies Vaccine received from Central Drug Laboratory, Kasauli was used to prepare the local reference standard and it was included in the in-house serological methods to validate the assay. Our in-house tests are found to be simple, rapid and cost effective and require less time when compared to in-vivo animal challenge and cell culture based in-vivo tests.
\end{abstract}

Keywords: Rabies vaccine; Immunization; Propagation

\section{Introduction}

Rabies is highly fatal disease of central nervous system caused by rabies virus belonging to genus Lyssavirus in the rhabdoviridae family. Rabies is one of the major causes of human mortality, annually 60,000 deaths are reported worldwide [1] and 20,000 deaths are reported in India [2]. Rabies can be prevented by effective vaccination with the combination of anti-rabies immunoglobulin [2]. Rabies vaccines produced in mammalian neural tissues (brain of adult animals such as sheep and goats; brain of suckling animals such as mouse, rat and rabbit) had been in use worldwide for many years. Their use had led to adverse reactions following immunization, such as encephalomyelitis and polyneuritis [3,4].

After the recommendation of WHO to ban the use of Neural Tissue vaccine, safe and potent vaccines manufactured by cell culture techniques (involving Vero cells, human diploid cell and chick embryo fibroblast cellas cell substrate for propagation of virus) are available and used for pre and post-exposure prophylaxis against rabies [1] all around the word. The tissue culture vaccine manufacturing process involves: cell culturing, virus propagation, harvesting, concentration, inactivation, purification and formulation [5]. Estimating the rabies virus protein content in intermediate biological product will guideto determine the yield of rabies viral protein and help to reduce the product loss during vaccine production. There are five major proteins in the rabies virus namely Nucleoprotein $(\mathrm{N})$, Phosphoprotein $(\mathrm{P})$, Matrix or Membrane protein (M), Glycoprotein (G) and RNA polymerase (L) (Mahshid). Glycoprotein and ribonucleoprotein components of inactivated rabies vaccine play an important role in conferring protection $[6,7]$.

The use of the conventional in-vivo challenge test for quantification of Rabies viral antigen is having various drawbacks like variability in test results, long duration of time and requires large number of animals [8-10]. Implementation of the 3Rs concepts (Replacement, Reduction, Refinement of animal experiment) by the manufactures is encouraged to limit animal requirement in vaccine testing an alternative for in-vivo methods [11]. Many serological methods have been proposed by several studies as an alternative tool for the estimation of the rabies antigens [9-15]. In our study we attempted to develop in-house assays for detection of Rabies Antigens in the intermediate tissue culture derived Rabies vaccine products.

\section{Materials and Methods}

\section{Experimental animals}

The albino Guinea pig in the weight range of 250-350 gand New Zealand white rabbit in the weight range of $1.5 \mathrm{~kg}$ bred in Pasteur Institute of India, Coonoor breeding facility which is registered under CPCSEA (Committee for the purpose of control and supervision of experiments on animals). The animals were maintained according to the guidelines of CPCSEA and use of these laboratory animals has the approval of Institutional Animal Ethics Committee (IAEC) of Pasteur Institute of India, Coonoor. 


\section{Preparation of hyper immune serum}

The sera against the rabies viral protein is the primary requirement for the development of In-house serological methods. The hyper Immune sera against rabies viral proteins were raised in two animal models-guinea pig (5 Nos.) and rabbit (2 Nos.) by immunizing the standard antigen preparations containing $8.0 \mathrm{IU} /$ dose of rabies viral proteins administered at weekly intervals. The rabies viral protein content in this antigen preparation was estimated in comparison with the national reference standard received from Central Research institute (CRI), Kasauli HP, India. The 8.0 IU of rabies viral protein in each dose of immunization was finalized to get the higher concentration antibody titre in the sera to compensate loss during purification with column.

Immunization schedule: $500 \mu$ of rabies virus antigen $(8.0 \mathrm{IU})$ and $500 \mu \mathrm{l}$ of freund's complete adjuvant (SigmaLot \#F-5881) were mixed thoroughly using syringe. The uniformity of the antigen-adjuvant mixing was ensured when the drop did not dissociate while placing on the surface of water [16]. One $\mathrm{ml}$ of prepared Antigen was administered by intramuscular route into each animal models as primary dose [17-19]. For second (on $7^{\text {th }}$ day) and third dose (on $14^{\text {th }}$ day) of immunization $500 \mu \mathrm{l}$ of viral antigen and $500 \mu \mathrm{l}$ of freund's incomplete adjuvant (SigmaLot \#F-5506) mixed properly and $1 \mathrm{ml}$ was administered by subcutaneous route [20]. From fourth dose to seventh dose of immunization $500 \mu \mathrm{l}$ of plain viral antigens were inoculatedby subcutaneous route, at weekly interval.

Blood collection: One week after the fourth dose the test bleed was done by heart puncture and two weeks after the seventh dose the final bleed was done for preparation of hyper immune sera. Heart puncture method of bleeding was preferred to avoid the haemolysis and it was done by trained technical personals. The serum was carefully separated and centrifuged at $2000 \mathrm{rpm}$ for $5 \mathrm{~min}$ to remove the cell debris.

\section{Purification of hyper immune sera by G50 column}

The sterile saturated ammonium sulphate solution was prepared and the serum samples were mixed with half the volume of saturated ammonium sulphate solutions. The pellet was collected by centrifugation at $3000 \mathrm{rpm}$ for $15 \mathrm{~min}$. and after $10 \mathrm{~min}$ incubation period at room temperature. The pellet was washed two times with sterile $0.01 \mathrm{M}$ Phosphate buffer saline and finally it was dissolved in Phosphate buffer saline and subjected for column purification.

Size exclusion chromatography: The sephatax G50 beads were swelled (Drenching) overnight in sterile PBS ( $\mathrm{pH} 7.4$ ) and poured into the glass tube of $380 \mathrm{~mm}$ of length and $12 \mathrm{~mm}$ of width (inner dia). G50 matrix waspacked to a height of $160 \mathrm{~mm}$ without any breakin the column and equilibrated with PBS. The precipitated sera was loaded at the top of the column at once and a slower flow rate was fixed. Release of the protein from the column was examined by treating a drop with $25 \%$ of sulphosalicilic acidtaken in a concave slide. The eluted, purified hyper immune sera was collected in sterile $2 \mathrm{ml}$ tube and kept at $-20^{\circ} \mathrm{C}$ for setting up of serological test.

\section{Rapid fluorescent focus inhibition test (RFFIT)}

The serum samples were heat inactivated at $56^{\circ} \mathrm{C}$ for $30 \mathrm{~min}$ and were diluted by doubling dilution in 96 well micro titre plate to cover the expected neutralizing capacity of the respective sample. Each diluted sample was mixed with 100 CCID50 of virus per $0.1 \mathrm{ml}$ and incubated at $37^{\circ} \mathrm{C}$ for $90 \mathrm{~min}$ in $5 \% \mathrm{CO}_{2}$ atmosphere for neutralization. Then 25,000 neuroblastoma-2A cells in $50 \mu$ l were added to each well and incubated for $40-48 \mathrm{~h}$ in $5 \% \mathrm{CO}_{2}$ atmosphere. The fluids were removed and the cells were fixed by the addition of $70 \%$ acetone in PBS and the plate was incubated at $-20^{\circ} \mathrm{C}$ for $30 \mathrm{~min}$. Anti-Rabies FITC antibody conjugate were added to each well after removing the fixative reagent and the plate was incubated for $30 \mathrm{~min}$ at $37^{\circ} \mathrm{C}$ for conjugation. The conjugation fluid was removed, the plate was washed gently with distilled water and one drop of glycerol carbonate bicarbonate buffer ( $\mathrm{pH} \mathrm{9.0)} \mathrm{was} \mathrm{added} \mathrm{to} \mathrm{all} \mathrm{the} \mathrm{wells.} \mathrm{The} \mathrm{fixed} \mathrm{and}$ stained plate was read using fluorescent microscope.

WHO reference standard rabies immunoglobulin was reconstituted to yield $2.0 \mathrm{IU} / \mathrm{ml}$. This was incorporated in the test along with the test samples. The last dilution showing no fluorescence was taken as $100 \%$ neutralization for both WHO reference standard and test serum samples. The antibody titre of the test sample in terms of $\mathrm{IU} / \mathrm{ml}$ was extrapolated in comparison with the WHO reference serum. To ensure the quantum of virus added for neutralization of each sample, back titration was performed for each test to qualify or to validate the concentration of virus added. Normal cell control and a negative serum control were also added to rule out the false positivity/nonspecific fluorescence. The performance of the test was declared to be qualified only when all validation criteria passed through.

\section{Test samples}

The tissue cultured viral harvest were pooled and concentrated to 10X using TFF (Tangential flow filtration) system using $100 \mathrm{KDa}$ molecular weight cut-off cassettes with phosphate buffer saline recirculation. Further the concentrated biological materials were subjected for inactivation with beta propiolactone and series of downstream processes like cellular DNA removal, purification of viral protein by HPCL system, $0.22 \mu$ filtration, formulation with preservatives and stabilizers. The inactivated samples were collected between these stages for the estimation of viral protein by serological assays because during these stages there is higher chance for the loss of inactivated rabies viral protein (product loss) which leads to reduction in yield of final vaccine.

\section{Dot-blotting}

The Dot-blotting is a solid-phase immune assay for antibody or antigen detection. $50 \mu \mathrm{l}$ of each intermediate vaccine product samples and local reference standard were blotted on the Nitrocellulose membrane and kept at $37^{\circ} \mathrm{C}$ for $30 \mathrm{~min}$. The membrane was blocked with 5\% Bovine Albumin Fraction V (RM 1113 Himedia) in TBS with $0.05 \%$ of Tween 20 . The membrane was then incubated with guinea pig hyper immune sera (Primary antibody) followed by conjugation with Alkaline Phosphatase labelled anti guinea pig anti rabbit IgG antibody conjugate (Sigma-Lot R124310) as secondary antibody and the colour was developed using BCIP \& NBT substrate system. Finally the intensity of the dots was measured by spectro densitometer as OD value.

\section{Sandwich enzyme linked immuno sorbent assay}

Sandwich ELISA is highly sensitive method to detect the target of interest by sandwiching between the antibody pairs. The guinea pig raised hyper immune sera was coated on the Costar E.I.A/R.I.A high Binding Flat Bottom 96 well plate. The plate was blocked with 2\% BSA in PBS containing $0.05 \%$ tween $20.100 \mu \mathrm{l}$ of each of the samples, PBS as blank and local reference standard were added to respective wells as 
per the layout and incubated at $37^{\circ} \mathrm{C}$ for $2 \mathrm{~h}$. The rabbit raised hyper immune sera was used as primary antibody followed by anti-rabbitalkaline phosphatase conjugate (Sigma-\#SLBK3154V) in the ratio of 1 : 20,000 as conjugate. The Phosphatase substrate (pNPP) was used for the colour development and the OD value was measured at $405 \mathrm{~nm}$ after completing the $20 \mathrm{~min}$ of incubation at dark and the results were documented.

\section{SDS-PAGE}

Sodium dodecyl sulphate-Poly acrylamide gel electrophoresis was done as described by Laemmli (1970) to separate the polypeptides on the basis of their molecular sizes. Separation of inactivated tissue culture rabies viral protein was done using 10\% separating gel with 5\% stacking gel under the electrical field in Bio Rad electrophoresis apparatus along with the protein marker (Bio Rad-Precision plus protein marker ranging $10 \mathrm{KDa}$ to $250 \mathrm{KDa}$ ). The protein in the gel was stained by sliver nitrate staining to visualize the separated proteins on the gel in comparison with the molecular weight marker.

\section{Western Blotting}

The rabies virus protein resolved gel was used for western blotting analysis to assess the reactogenicity of the polyclonal hyper immune sera with the different proteins of the rabies virus. The viral proteins in the SDS PAGE gel was transferred to nitrocellulose membrane using Mini Trans-Blot tank (Bio-Rad) and electro blotted under $80 \mathrm{~V}$ for about $30 \mathrm{~min}$. Upon the completion of the run, the blotting sandwich was disassembled carefully and the membrane was removed from the sandwich for further development. Further processing were done as per the protocols of Dot Blotting assay described under 2.5 above.
Himachal Pradesh by NIH potency analysis in mice model. This local reference standard wasincluded as standard in all the serological methods. In Dot-blotting and ELISA, a standard curve was developed plotting the reading of the known antigen content (Figure 2,3). The concentration of unknown samples was extrapolated using this standard curve.

\section{Results}

\section{Hyper immune serum}

Antisera against the rabies is the primary requirement for the development of serological assay for rabies viral protein. Purified preparations of rabies antigen preparation having rabies viral protein of $8 \mathrm{IU} / 0.5 \mathrm{ml}$ in each dosewas used in this study for raising antisera. The US Centers for Disease Control has recommended the minimum protective antibody titer as either $\geq 1: 5$ (using the rapid fluorescent inhibition technique) or $\geq 0.5 \mathrm{IU} / \mathrm{mL}$ (using the mouse neutralization test) [21] it was observed much higher antibody titre in both the immunized animal models. The antibody titre was measured using RFFIT method. The antibody titre in test bleed samples (one week after the fourth dose) showed in Guinea pigs ranging from $128 \mathrm{IU}$ to $400 \mathrm{IU}$ per $\mathrm{ml}$ and in the case of Rabbits it was 400 IU per $\mathrm{ml}$. 100\% survival rate of animals were achieved during this test bleed. At the time of final bleed (two week after the seventh dose) the guinea pig antibody ranged from $800 \mathrm{IU}$ to $2400 \mathrm{IU}$ per $\mathrm{ml}$ and the rabbit antibody was $600 \mathrm{IU}$ per $\mathrm{ml}$ (Table 1). The details of biological intermediate sample subjected for serological analysis were well described in materials and methods chapter 2.5.

\section{Local reference standard \& standard curve}

The local reference standard was preparedusing the national reference standard provided by Central Drug laboratory, Kasauli,

\begin{tabular}{|c|c|c|c|}
\hline S.No & Sample ID & Ab titre ( 1 week from $4^{\text {th }}$ dose) & Ab titre ( 2 week from $7^{\text {th }}$ dose) \\
\hline 1 & G.Pig 1 & $\geq 128 \mathrm{IU} / \mathrm{ml}$ & $400 \mathrm{IU} / \mathrm{ml}$ \\
\hline 2 & G.Pig 2 & $\geq 128 \mathrm{IU} / \mathrm{ml}$ & $800 \mathrm{IU} / \mathrm{ml}$ \\
\hline 3 & G.Pig 3 & $400 \mathrm{IU} / \mathrm{ml}$ & $\geq 2400 \mathrm{IU} / \mathrm{ml}$ \\
\hline 4 & G.Pig 4 & $400 \mathrm{IU} / \mathrm{ml}$ & $800 \mathrm{IU} / \mathrm{ml}$ \\
\hline 5 & G.Pig Control & $0 \mathrm{IU} / \mathrm{ml}$ & $0 \mathrm{IU} / \mathrm{ml}$ \\
\hline 6 & Rabbit 1 & $400 \mathrm{IU} / \mathrm{ml}$ & $600 \mathrm{IU} / \mathrm{ml}$ \\
\hline 7 & Rabbit 2 & $400 \mathrm{IU} / \mathrm{ml}$ & $600 \mathrm{IU} / \mathrm{ml}$ \\
\hline
\end{tabular}

Table 1: Antibody raise in each animal models analysed by RFFIT.

\section{Dot-blotting}

The concentration of rabies antigen in test samples was measured by using Dot Blot analysis (Figure 1). The local reference standard was diluted to attain different concentrations of $0.125 \mathrm{IU}, 0.25 \mathrm{IU}, 0.5 \mathrm{IU}, 1$ IU, 2 IU and $4 \mathrm{IU}$ and one negative control was included in this test and were blotted in the upper row and the test samples were blotted in the lower row of the membrane. The OD value of the respective dot was measured using spectro densitometer are shown in Table 2. The standard graph was plotted for different concentrations of antigen standard. We observed a gradient increase in the intensity of the optical density in line with the increasing concentration of antigen (Figure 2). The antigen concentration of the test sample was determined by extrapolating the OD values on the standard graph as shown in (Table 2). 
Citation: Sekar T, ChandraMohan G, Palaniappan C, Premkumar AA, Sundaran B, et al. (2018) Development of In-vitro Assays to Estimate Rabies Viral Protein in Vaccine Preparation. J Vaccines Vaccin 9: 392. doi:10.4172/2157-7560.1000392

Page 4 of 6

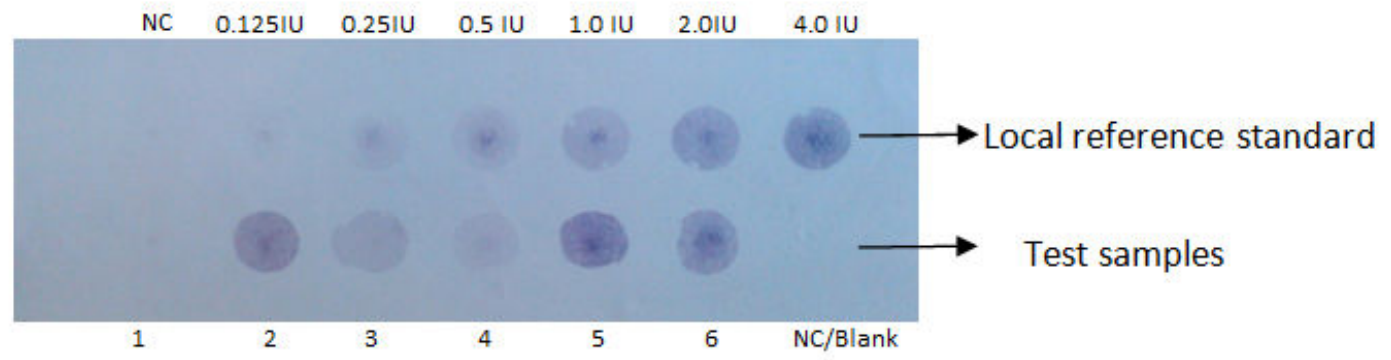

Figure 1: Dot Blot Analysis of rabies viral antigen concentration in test samples with local reference standard. (Sample ID: 1: Permeate while concentration, 2: Concentrated material-1, 3: Concentrated Material-2, 4: Protamine sulphate precipitate, 5: HPLC protocol 1, 6: HPLC protocol 2)

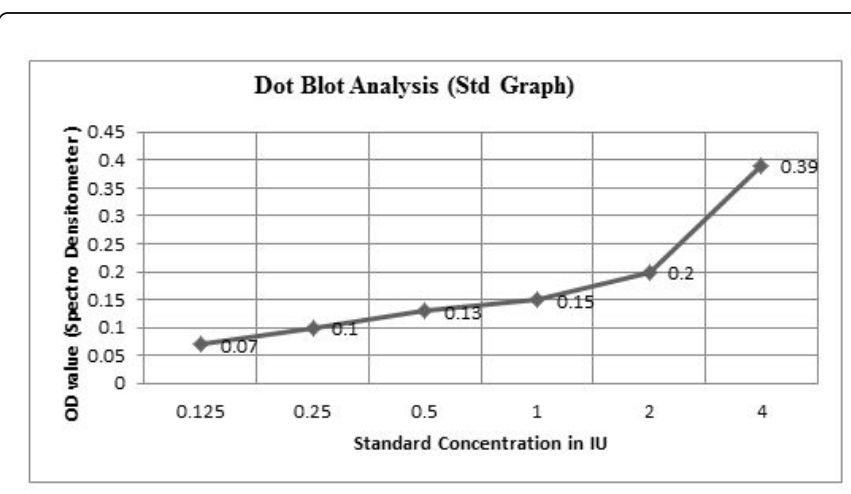

Figure 2: The standard graph of Dot blot ELISA (X axis-the concentration of Antigen, $\mathrm{Y}$ axis-OD value of different concentration).

\begin{tabular}{|l|l|l|l|l|l|l|l|}
\hline \multicolumn{2}{|l}{ DOT BLOT - OD value (Spectro Densitometer) } \\
\hline STD CON inIU & NC & 0.125 & 0.25 & 0.5 & 1 & 2 & 4 \\
\hline OD of STD & 0.05 & 0.07 & 0.1 & 0.13 & 0.15 & 0.2 & 0.39 \\
\hline Samples & NC & S 1 & S2 & S3 & S4 & S5 & NC \\
\hline OD of samples & 0.05 & 0.19 & 0.12 & 0.08 & 0.37 & 0.22 & 0.05 \\
\hline CON in IU & Blank & 1.75 & 0.45 & 0.21 & 3.75 & 2.21 & Blank \\
\hline
\end{tabular}

Table 2: Quantification of Rabies viral antigen content by Dot Blot Analysis (NC-Negative Control, CON-Concentration, OD-Optical Density, STD-Standard, IU-International Unit).

\section{Sandwich ELISA}

The sandwich ELISA was performed for the different test samples along with media blank, local reference standard in different concentrations of $0.5 \mathrm{IU}, 1 \mathrm{IU}, 2 \mathrm{IU}, 3 \mathrm{IU}$ and $4 \mathrm{IU}$. The OD values measured at $405 \mathrm{~nm}$ in ELISA 96 well plate reader. A standard curve was plotted with the different concentration of standards included in this assay procedure (Figure 3). The intensity of the substrate colour was observed to be directly proportional to the concentration of the rabies antigen. The test sample rabies antigen quantity were extrapolated using the standard graph, as shown in Table 3.

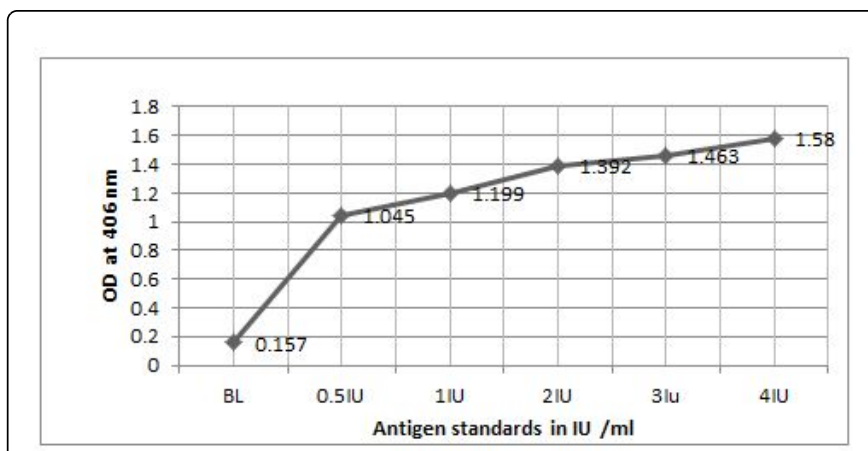

Figure 3: Standard graph Sandwich ELISA (X axis-the concentration of Antigen standard, $\mathrm{Y}$ axis-OD value).

\begin{tabular}{|l|l|l|l|l|l|}
\hline \multicolumn{7}{|l|}{ SANDWICH ELISA- OD value at $405 \mathrm{~nm}$} \\
\hline OD & Std. Con. & OD & Conc & OD & Conc \\
\hline 0.157 & Blank & 1.008 & $0.5 \mathrm{IU}$ & 0.392 & $<0.5 \mathrm{IU}$ \\
\hline 1.045 & $0.5 \mathrm{IU}$ & 1.333 & $1.7 \mathrm{IU}$ & 0.183 & Blank \\
\hline 1.199 & $1 \mathrm{IU}$ & 1.417 & $2.2 \mathrm{IU}$ & 0.793 & $<0.5 \mathrm{IU}$ \\
\hline 1.392 & $2 \mathrm{IU}$ & 1.053 & $0.5 \mathrm{IU}$ & 0.176 & Blank \\
\hline 1.463 & $3 \mathrm{IU}$ & 0.172 & Blank & 0.26 & $<0.5 \mathrm{IU}$ \\
\hline 1.58 & $4 \mathrm{IU}$ & 0.183 & Blank & 0.195 & Blank \\
\hline
\end{tabular}

Table 3: Quantification of Rabies viral antigen content by Sandwich ELISA Analysis (NC-Negative Control, CON-Concentration, ODOptical Density, Std. Con.-Standard Concentration, IU-International Unit).

\section{SDS-PAGE}

The protein profile of the antigen was studied by the electrophoresis using 10\% SDS PAGE. Rabies Viral genome encodes five different types of proteins namely Nucleoprotein-N (55 KDa), Phosphoprotein-M1 $(40 \mathrm{KDa})$, Matrix or Membrane protein-M2 (26 KDa), Glycoprotein-G 
(64 KDa) and RNA-dependent RNA polymerase-L (190 KDa). The different proteinsof the rabies viral antigen were observed in the SDSPAGE in the silver stained gel.

\section{Western Blotting}

The western blotting is the highly sensitive method to confirm the presence of specific protein in the sample subjected for this test. The reactogenicity of the raised hyper immunesera against the different antigens of the rabies virus was studied by the in-house western blotting procedure.

Four test samples were included in this method and the bands were developed by the immunochemical reaction between the rabies antigen and hyper immune sera raised. The different protein fractions of the rabies virus were clearly observed on the nitrocellulose membrane (Figure 4). This polyclonal guinea pig hyper immune sera reacted with all the rabies viral protein fractions (samples) and there is no reaction with ladder lane due to non binding of antibody with ladder protein.

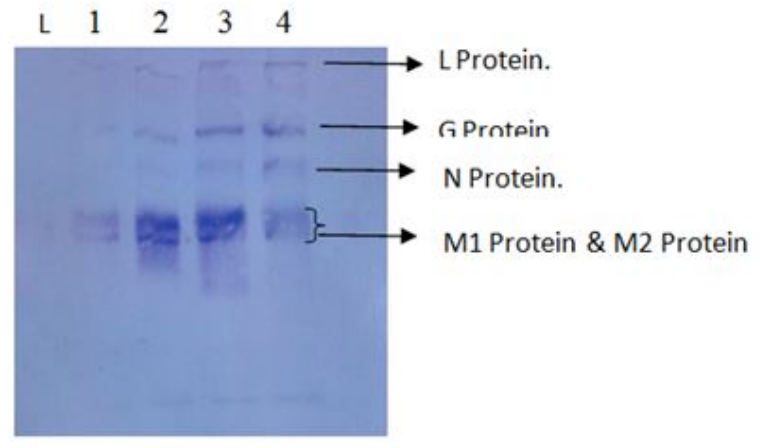

Figure 4: Western Blotting Analysis: Rabies viral specific antigens reacted with guinea pig raised polyclonal hyper immune sera (Samples ID 1: inactivated fluid, 2: Concentated Biological material, 3: HPLC Protocol -1, 4: HPLC protocol-2).

\section{Discussion}

Conventionally the in-vivo and in-vitro methods are employed for the estimation of rabies viral antigen during the intermediate steps of rabies vaccine production. The conventional NIH potency (in-vivo test) method has some limitation; since the test involves the use of more animals and requires 28 days time period. The Antibody Binding Test (ABT) (in-vitro) requires sophisticated cell culture lab facility. The dot blot enzyme immuno assay (serological assay) was shown to be sensitive, specific and rapid alternative method for FAT (Fluorescent Antibody Test) for the detection of rabies antigen from post-mortem brain specimens of human $[17,18]$. Immune capture ELISA has been recommended to estimate the rabies viral glycoprotein antigen content in the inactivated rabies antigen preparation, in a simple and rapid format, which enables better vaccine formulation [13]. The reference vaccine included in each test shall be calibrated in International Units by comparison with the International standard for rabies vaccine. The Potency of the test vaccine in International Units shall be determined by comparing its activity with that of the reference vaccine in the NIH test [7]. It was reported that the in-vitro ELISA method is one the alternative method to check the potency of rabies vaccine in place of in-vivo NIH test and the outcome of the ELISA results showed to be correlating with $\mathrm{NIH}$ test $[12,13]$. In our study we used Guinea pig and rabbit as animal models to raise rabies hyper immune sera against rabies virus since it facilitated sufficient volume of serum for the purification with column and setting up of serological method. The rabies viral antigen immunization induced the antibody response in the guinea pig and rabbit which was further purified by saturated ammonium sulphate precipitation and sephadexG50 column. After the completion of the immunization Guinea Pig showed serum titre ranging from $800 \mathrm{IU}$ to $2400 \mathrm{IU}$. In the case of Rabbits, the titre ranged between $400 \mathrm{IU} / \mathrm{ml}$ to $600 \mathrm{IU} / \mathrm{ml}$. Five different samples drawn at different stages of production of Tissue culture anti-rabies vaccine were analysed for rabies antigen concentration by serological methods such as Dot Blotting and sandwich ELISA.

The local reference standard was included in Dot Blotting and Sandwich ELISA to validate the assays, and we observed that there was exponential increase in the intensity of OD value in correlation with the concentration of rabies antigen. Both Dot blot and sandwich ELISA methods detected the rabies antigens and enabled to determine the antigen concentration. The detection limits of the two methods were comparable with each other. The intensity of the colour in dot blot was more in the case of the lower antigen concentration when compared to the sandwich ELISA. If the incubation with the substrate solution was prolonged the blots with higher antigen concentration turned darker making the reading difficult. Hence we followed a strategy to terminate the reaction immediately soon after the lowest concentration in standard developed colour. The Limit of Antigen detection by the dot blotting and sandwich ELISA are comparable with the conventional in-vivo/in-vitro methods. Further the key samples were resolved in $10 \%$ SDS-PAGE, and the different proteins profile of the rabies virus were observed. The in-house western blotting confirmed that the hyper immune sera was raised reacted to all the protein fraction of rabies antigen.

\section{Conclusion}

Detection and quantification of the viral protein in the intermediate biological product is very crucial step and it is helpful to reduce the product loss during the vaccine manufacturing. The in-house serological methods developed by us can be used for detection and quantification of rabies antigens in intermediate biological products during vaccine preparation and also it can be implemented to test the potency of final vaccine after due validation of these assay protocols. In comparison to conventional methods, our in-house methods are simple, cost effective, rapid and no animal facility and no cell culture facilities are required.

\section{References}

1. Khaled T, Samia R, Houssem L, Samy M, H'elaKallel (2005) Comparison of various culture modes for the production of rabies virus by Vero cells grown on microcarriers in a 2-1 bioreactor. Enzyme Microb Technol 36: 514-519.

2. Sridevi VN, Shukra MA, Neelakantam B, Varaprasada SR, Rajalakshmi S, et al. (2010) Recombinant Diabody-Based Immunocapture EnzymeLinked Immunosorbent Assay for Quantification of Rabies Virus Glycoprotein. Clin Vaccine Immunol 17: 1261-1268.

3. WHO TRS (2007) 941: Annex - 2.

4. Birhanu H, Abebe M, Bethlehem N, Sisay K, Gezahegn K, et al. (2013) Production of Cell Culture Based Anti- rabies Vaccine in Ethiopia. SciVerse Science Direct procedia in vaccinology 7: 2-7. 
Citation: Sekar T, ChandraMohan G, Palaniappan C, Premkumar AA, Sundaran B, et al. (2018) Development of In-vitro Assays to Estimate Rabies Viral Protein in Vaccine Preparation. J Vaccines Vaccin 9: 392. doi:10.4172/2157-7560.1000392

Page 6 of 6

5. Neuza MFG, Regina MMF, Rosana LP, Maria L, Silva N, et al. (2004) Vero cell rabies vaccine produced using serum free medium. vaccine 23: 511-517.

6. Mahshid D, Pooneh R, Setareh H, Peyvand B, Nader H, et al. (2014) Cell culture extraction and purification of rabies virus nucleoprotein Jundishapur J Microbiol 7: eII734.

7. WHO TRS (1994) 840: Annex - 4.

8. Stokes WMR, Kulpa EJ, Gatewook D, Levis R, Halder M, et al. (2012) Report of the international workshop on alternative method for human and veterinary rabies vaccine testing; state of the science and planning the way forward. Biologicals 40: 369-381.

9. Barth R, Diderrich G, Weinman E (1988) NIH test, a problematic method for testing potency of inactivated rabies vaccine. Vaccine 6: 369-377.

10. Gontu A, Scott D, Adabala S, Senthilkumar RL, Vidyasagar P, et al. (2014) A novel site-II directed glycoprotein estimation ELISA to aid rabies vaccine manufacture for veterinary and human use. Vaccine 32: 209-213.

11. Jacqueline FC, Poirier B, Haond G, Jallet C, Fuchs F, et al. (2003) Inactivated rabies vaccine control and release: use of ELISA method. Biologicals 31: 9-16.

12. Richard G, Monique A, Bertrand P, Corinne J, Noel T, et al. (2013) A relevant in vitro ELISA test in alternative to the in vitro NIH test for human rabies vaccine batch release. Vaccine 31: 6022-6029.

13. Nagarajan T, Reddy GS, Subramanian BM, Rajalakshmi S, Thiagarajan D, et al. (2006) A simple immune-capture ELISA to estimate rabies viral glycoprotein antigen in vaccine manufacture. Biologicals 34: 21-27.
14. Rooijakkers EJM, Uittenbogaard JP, Groen J, Osterhaus ADME (1996) Rabies vaccine potency control, comparison of ELISA systems for antigenicity testing. J Virol Methods 58: 111-119.

15. Maas RA, De Winter MPM, Venema S, Oei HL, Claassen JTM (2000) Antigen Quantification as IN VITRO alternative for potency testing of inactivated viral poultry vaccine. Vet Q 22: 223-227.

16. Weir DM (1978) Handbook of Experimental Immunology, Third Edition, Blackwell scientific publications.

17. Jayakumar R, Nachimuthu K, Padmanaban VD (1995) A Dot enzyme linked immunosorbent assay (Dot ELISA) comparison with standard fluorescent antibody test (FAT) for the diagnosis of rabies in animals. Comp Immunol Microbiol Infect Dis 18: 269-273.

18. Madhusudana SN, Paul JPV, Abhilash VK, Suja MS (2004) Rapid diagnosis of rabies in, humans and animals by dot blot enzyme immunoassay. Int J Infect Dis 8: 339-345.

19. Ricardo SC, Andréa de Cássia RS, Alexandre MB, Luciana BC, Rita BB (2010) Equivalence between pre-exposure schemes for human rabies and evaluation of the need for serological monitoring. Rev Saúde Pública 44: 548-554.

20. Luekrajang T, Wangsai J, Phanuphak P (1996) Production of antirabies serum of equine origin. Laboratory Techniques in rabies 4 th edition, WHO Geneva 44: 401-404.

21. ACIP (1999) Centers for Disease Control and Prevention . Human Rabies Prevention- United States. Recommendations of the advisory committee on immunization practices. MMWR Recomm Rep 48: 1-21. 